\title{
Investigation of previously implicated genetic variants in chronic tic disorders: a transmission disequilibrium test approach
}

\author{
Mohamed Abdulkadir ${ }^{1,2}$ (D) Douglas Londono ${ }^{1} \cdot$ Derek Gordon $^{1} \cdot$ Thomas V. Fernandez $^{3} \cdot$ Lawrence W. Brown $^{4}$. \\ Keun-Ah Cheon ${ }^{5}$ Barbara J. Coffey ${ }^{6,7} \cdot$ Lonneke Elzerman $^{8} \cdot$ Carolin Fremer $^{9} \cdot$ Odette Fründt $^{10}$ . \\ Blanca Garcia-Delgar ${ }^{11}$ • Donald L. Gilbert ${ }^{12}$ • Dorothy E. Grice ${ }^{6} \cdot$ Tammy Hedderly $^{13}$ - Isobel Heyman ${ }^{14}$. \\ Hyun Ju Hong ${ }^{15}$. Chaim Huyser ${ }^{16,17}$ • Laura Ibanez-Gomez ${ }^{6,7}$ • Ewgeni Jakubovski ${ }^{9}$ Young Key Kim ${ }^{18}$. \\ Young Shin Kim ${ }^{19} \cdot$ Yun-Joo Koh $^{20} \cdot$ Sodahm Kook $^{21} \cdot$ Samuel Kuperman $^{22}$ • Bennett Leventhal ${ }^{19}$. \\ Andrea G. Ludolph $^{23} \cdot$ Marcos Madruga-Garrido $^{24}$ - Athanasios Maras ${ }^{8,25}$ • Pablo Mir ${ }^{26}$ • Astrid Morer ${ }^{27,11}$. \\ Kirsten Müller-Vahl ${ }^{9}$ - Alexander Münchau ${ }^{28}$ - Tara L. Murphy ${ }^{14}$ - Kerstin J. Plessen ${ }^{29}$ • Veit Roessner ${ }^{30}$. \\ Eun-Young Shin ${ }^{5}$ - Dong-Ho Song ${ }^{5}$ Jungeun Song ${ }^{31} \cdot$ Jennifer Tübing $^{28} \cdot{\text { Els van den } \text { Ban }^{32} \text { • Frank Visscher }}^{33}$. \\ Sina Wanderer ${ }^{30} \cdot$ Martin Woods $^{13} \cdot$ Samuel H. Zinner ${ }^{34} \cdot$ Robert A. King $^{3}$. Jay A. Tischfield ${ }^{1}$ - Gary A. Heiman ${ }^{1}$. \\ Pieter J. Hoekstra ${ }^{2} \cdot$ Andrea Dietrich $^{2}$
}

Received: 3 November 2016 / Accepted: 17 May 2017 / Published online: 29 May 2017

(C) The Author(s) 2017. This article is an open access publication

\begin{abstract}
Genetic studies in Tourette syndrome (TS) are characterized by scattered and poorly replicated findings. We aimed to replicate findings from candidate gene and genome-wide association studies (GWAS). Our cohort included 465 probands with chronic tic disorder (93\% TS) and both parents from 412 families (some probands were
\end{abstract}

Electronic supplementary material The online version of this article (doi:10.1007/s00406-017-0808-8) contains supplementary material, which is available to authorized users.

Deceased: Andrea G. Ludolph.

Gary A. Heiman, Pieter J. Hoekstra, and Andrea Dietrich have contributed equally to this work.

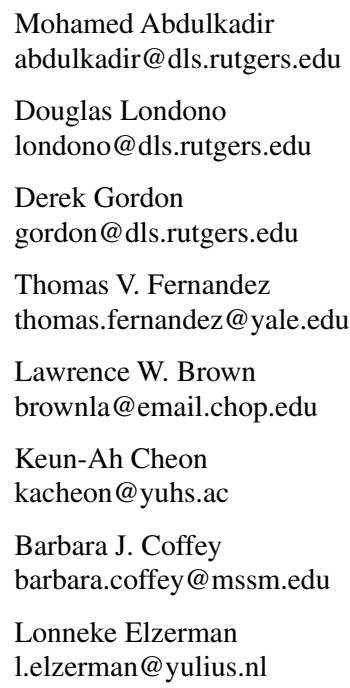

siblings). We assessed 75 single nucleotide polymorphisms (SNPs) in 465 parent-child trios; 117 additional SNPs in 211 trios; and 4 additional SNPs in 254 trios. We performed SNP and gene-based transmission disequilibrium tests and compared nominally significant SNP results with those from a large independent case-control cohort. After quality control 71 SNPs were available in 371 trios; 112 SNPs in 179 trios; and 3 SNPs in 192 trios. 17 were candidate SNPs implicated in TS and 2 were implicated in obsessive-compulsive disorder (OCD) or autism spectrum disorder (ASD); 142 were tagging SNPs from eight monoamine neurotransmitter-related genes (including dopamine and serotonin); 10 were top SNPs from TS GWAS; and 13 top

\author{
Carolin Fremer \\ fremer.carolin@mh-hannover.de \\ Odette Fründt \\ odette.schunke@gmx.net \\ Blanca Garcia-Delgar \\ bgarciad@clinic.ub.es \\ Donald L. Gilbert \\ donald.gilbert@cchmc.org \\ Dorothy E. Grice \\ dorothy.grice@mssm.edu \\ Tammy Hedderly \\ tammy.hedderly@gstt.nhs.uk \\ Isobel Heyman \\ i.heyman@ucl.ac.uk
}


SNPs from attention-deficit/hyperactivity disorder, OCD, or ASD GWAS. None of the SNPs or genes reached significance after adjustment for multiple testing. We observed nominal significance for the candidate SNPs rs3744161 (TBCD) and rs4565946 (TPH2) and for five tagging SNPs; none of these showed significance in the independent cohort. Also, SLC1A1 in our gene-based analysis and two TS GWAS SNPs showed nominal significance, rs11603305 (intergenic) and rs621942 (PICALM). We found no convincing support for previously implicated genetic polymorphisms. Targeted re-sequencing should fully appreciate the relevance of candidate genes.

Keywords Attention-deficit/hyperactivity disorder . Candidate gene study - Obsessive-compulsive disorder . Tourette syndrome $\cdot$ Transmission Disequilibrium Test

\section{Introduction}

Both family and twin studies have consistently suggested a genetic etiology of Tourette syndrome (TS), a common childhood-onset tic disorder [1]. The strong heritability has led to a wide range of gene finding efforts, which initially, prior to the initiation of genome-wide association studies (GWAS) focused on family-based linkage and candidategene-based case-control studies [1,2]. These candidate genes have typically been selected based on prevailing theories of the etiology of TS. There has now been a considerable number of candidate genes studies which have attempted to confirm theories on neurotransmitter involvement in TS [2]. However, the field of candidate gene studies is characterized by poorly replicated findings using mostly small sample sizes [1,2]. For example, while the dopamine receptor D2 (DRD2) gene was implicated by Comings et al. [3] this finding could not be replicated in a subsequent study led by Díaz-Anzaldúa et al. [4]. Currently, we lack a comprehensive and independent synthesis of the various putative genetic loci identified from candidate gene studies.

Neurotransmitter-related candidate gene studies in TS have been based on post-mortem brain findings [5], therapeutic responses to antipsychotics [5], pathophysiological studies [5], or genetic linkage studies [2]; and have included genes related to the neurotransmitter pathways dopamine, glutamate, histamine, and serotonin [2,5]. The classical principle guiding the investigation of candidate genes in these pathways has been the thought that certain single nucleotide polymorphisms (SNPs) within these genes might impact protein functions required for normal neurotransmission.

The one published GWAS study of TS to date [6] did not result in findings with genome-wide significance, possibly due to lack of power to detect common variants of small effects. A subsequent study [7] looking into the top SNPs

\author{
Hyun Ju Hong \\ honghj88@gmail.com \\ Chaim Huyser \\ c.huyser@debascule.com \\ Laura Ibanez-Gomez \\ laura.ibanez.gomez@gmail.com \\ Ewgeni Jakubovski \\ jakubovski.ewgeni@mh-hannover.de \\ Young Key Kim \\ psykay@ hanmail.net \\ Young Shin Kim \\ youngshin.kim@ucsf.edu \\ Yun-Joo Koh \\ yunjoo@ rudolph.co.kr \\ Sodahm Kook \\ damiso777@hotmail.com \\ Samuel Kuperman \\ samuel-kuperman@uiowa.edu \\ Bennett Leventhal \\ bennett.leventhal@ucsf.edu \\ Andrea G. Ludolph \\ andrea.ludolph@uni-ulm.de \\ Marcos Madruga-Garrido \\ mmadruga@us.es
}

\author{
Athanasios Maras \\ a.maras@yulius.nl \\ Pablo Mir \\ pmir@us.es \\ Astrid Morer \\ amorer@clinic.ub.es \\ Kirsten Müller-Vahl \\ mueller-vahl.kirsten@mh-hannover.de \\ Alexander Münchau \\ alexander.muenchau@neuro.uni-luebeck.de \\ Tara L. Murphy \\ tara.murphy@gosh.nhs.uk \\ Kerstin J. Plessen \\ kerstin.plessen@ regionh.dk \\ Veit Roessner \\ veit.roessner@uniklinikum-dresden.de \\ Eun-Young Shin \\ jk817@hanmail.net \\ Dong-Ho Song \\ dhsong@yuhs.ac \\ Jungeun Song \\ songdr90@hanmail.net \\ Jennifer Tübing \\ jennifer.tuebing@neuro.uni-luebeck.de
}


was only able to find significance for a SNP (rs2060546) in the Netrin 4 gene (NTN4), following correction for multiple statistical comparisons. However, this study [7] and others [8] have not replicated the original top TS GWAS signal (rs7868992) [6] in the Collagen Type XXVII Alpha 1 gene (COL27A1).

The aim of the present study was to independently replicate findings of candidate SNPs and candidate genes previously implicated in TS or related disorders that are often comorbid with TS, i.e., obsessive-compulsive disorder (OCD), attention-deficit/hyperactivity disorder (ADHD), and autism spectrum disorder (ASD) [9], given a potential shared genetic susceptibility [2]. We investigated a total of 196 SNPs that included the following: individual candidate SNPs; tagging SNPs (tSNPs) covering neurotransmitterrelated candidate genes; top SNPs from TS GWAS; and top SNPs from GWAS of related disorders. Analyses were performed as part of the Tourette International Collaborative Genetics (TIC Genetics, [10]) study, and consisted of 465 children with a chronic tic disorder and both parents. The selected genetic loci were investigated in relation to the presence of a chronic tic disorder in SNP and gene based transmission disequilibrium tests (TDT) analyses. The use of the TDT is a major advantage above a case-control design as it ensures proper control for population stratification with no need for a separate control group [11].

\section{Methods}

\section{Study subjects}

This study included 465 parent-child trios from 412 families (some parents formed trios with more than one affected child), with probands affected with a chronic tic disorder, of whom $93 \%$ had TS and $7 \%$ a chronic motor or vocal tic disorder. Probands $(77.8 \%$ males; mean age $=13.9$, $\mathrm{SD}=6.42$, range $4-52$ years) and their biological parents were from the Tourette International Collaborative Genetics (TIC Genetics, [10]) study, recruited between 2011 and 2014 across 24 sites in the USA, Europe, and South Korea (360 parent-child trios); the New Jersey Center for Tourette Syndrome (NJCTS) [12] between 2006 and 2010 (102 parent-child trios); or the Yale Child Study Center in 2007 (three parent-child trios). The TIC Genetics study was established as a comprehensive gene discovery effort for TS, with a focus on multiply-affected family pedigrees and cases without a family history of tics. Inclusion criteria of cases were presence of a chronic tic disorder according to the Diagnostic and Statistical Manual of Mental Disorders Fourth edition, Text Revision (DSM-IV-TR, [13]) and donation of DNA by the proband and both biological parents. Before enrolling in the study, all adult participants and parents of children provided written informed consent

\author{
Els van den Ban \\ e.van.den.ban@altrecht.nl \\ Frank Visscher \\ f.visscher@adrz.nl \\ Sina Wanderer \\ sina.wanderer@uniklinikum-dresden.de \\ Martin Woods \\ martin.woods@gstt.nhs.uk \\ Samuel H. Zinner \\ szinner@uw.edu \\ Robert A. King \\ robert.king@yale.edu \\ Jay A. Tischfield \\ jay@dls.rutgers.edu \\ Gary A. Heiman \\ heiman@dls.rutgers.edu \\ Pieter J. Hoekstra \\ p.hoekstra@accare.nl \\ Andrea Dietrich \\ a.dietrich@accare.nl \\ 1 Department of Genetics, Human Genetics Institute of New \\ Jersey, Rutgers, The State University of New Jersey, \\ Piscataway, NJ, USA
}

2 Department of Child and Adolescent Psychiatry, University Medical Center Groningen, University of Groningen, Groningen, The Netherlands

3 Department of Psychiatry, Yale Child Study Center, Yale University School of Medicine, New Haven, CT, USA

4 Children's Hospital of Philadelphia, Philadelphia, PA, USA

5 Yonsei University College of Medicine, Yonsei Yoo \& Kim Mental Health Clinic, Seoul, South Korea

6 Division of Tics, OCD and Related Disorders, Department of Psychiatry, Icahn School of Medicine at Mount Sinai, New York, NY, USA

7 Nathan S. Kline Institute for Psychiatric Research, Orangeburg, NY, USA

8 Yulius Academy and Division Child and Adolescent Psychiatry, Yulius Mental Health Organization, Barendrecht, The Netherlands

9 Medizinische Hochschule Hannover Klinik für Psychiatrie, Sozialpsychiatrie und Psychotherapie, Hannover, Germany

10 University Hospital Medical Center Hamburg-Eppendorf, Hamburg, Germany

11 Department of Child and Adolescent Psychiatry and Psychology, Institute of Neurosciences, Hospital Clinic Universitari, Barcelona, Spain 
along with written or oral assent of their participating child. The Institutional Review Board of each participating site had approved the study.

\section{Clinical measures}

Experienced clinicians assigned a clinical diagnosis of a tic disorder and assessed the possible presence of comorbid OCD and/or ADHD based on DSM-IV-TR criteria, as described elsewhere in more detail [10].

\section{Selection of single nucleotide polymorphisms}

Selection of TS candidate SNPs and genes was based on review articles [1,2] and PubMed searches using the terms "Tourette", "tics", and "TS" in combination with the terms "candidate gene" or "association study", of literature published until October 2014. We selected 196 SNPs, including: (a) 17 individual candidate SNPs previously reported to be at least nominally significantly $(P$ value $<0.05)$ associated with TS; (b) 2 individual candidate SNPs previously associated with OCD and ASD, respectively; (c) 148 tSNPs covering seven neurotransmitter-related candidate genes of which at least one polymorphism had previously been reported to be at least nominally significantly ( $P$ value $<0.05)$ associated with either TS $(D R D 2, H D C, M A O-A$,

12 Cincinnati Children's Hospital Medical Center, Cincinnati, $\mathrm{OH}$, USA

13 Evelina London Children's Hospital GSTT, Kings Health Partners AHSC, London, UK

14 Great Ormond Street Hospital for Children, and UCL Institute of Child Health, London, UK

15 Hallym University Sacred Heart Hospital, Anyang, South Korea

16 De Bascule, Amsterdam, The Netherlands

17 AMC Department of Child and Adolescent Psychiatry, Amsterdam, The Netherlands

18 Yonsei Bom Clinic, Seoul, South Korea

19 Department of Psychiatry, University of California, San Francisco, USA

20 Korea Institute for Children's Social Development, Seoul, South Korea

21 Kangbuk Samsung Hospital, Seoul, South Korea

22 University of Iowa Carver College of Medicine, Iowa City, IA, USA

23 Department of Child and Adolescent Psychiatry and Psychotherapy, University of Ulm, Ulm, Germany

24 Sección de Neuropediatría, Instituto de Biomedicina de Sevilla, Hospital Universitario Virgen del Rocío/CSIC/ Universidad de Sevilla, Seville, Spain
SLC6A3/DAT1, and TPH2, reviewed in [2]) or a related disorder (SLC1A1 and GABRA2, associated with, respectively, OCD and ASD [14, 15]), in addition to HRH3 (which has never been investigated in relation to TS, but was included based on the possible involvement of genes related to histamine $[16,17])$; tSNP selection was restricted to common SNPs (minor allele frequency $>0.05$ ) and were selected using the HapMap CEU population as a reference and the Tagger algorithm implemented in Haploview [18, 19]. The $\mathrm{R}^{2}$ threshold for the tSNP selection was set at 0.8 . To capture possible regulatory variants, we also included tSNPs $10 \mathrm{~kb}$ upstream and downstream of each gene (see supplementary Table S1). (d) 12 TS GWAS-based top SNPs, i.e., the top 5 LD-independent SNPs from the first GWAS of TS [6], 4 top SNPs from the Gilles de la Tourette Syndrome Genome-Wide Association Study Replication Initiative [7], and the top 3 SNPs from the first cross-disorder GWAS of TS and OCD [20]; and (e) 17 top SNPs from GWAS studies of OCD [21], ADHD [22, 23], and ASD [24, 25]. We did not include the previously implicated TS SNPs rs 1894236 (HDC), rs1056534 (TBCD), rs25531 (SLC6A4), rs25532 (SLC6A4), nor tSNPs covering the possible TS candidate genes DRD4, Arylacetamide Deacetylase (AADAC) [26, 27], and Glial Cell Derived Neurotrophic Factor (GDNF) [27], nor 19 SNPs recently implicated in a meta-analysis of TS and ADHD [28].

25 Department of Child and Adolescent Psychiatry, Erasmus Medical Center-Sophia Children's Hospital, Rotterdam, The Netherlands

26 Unidad de Trastornos del Movimiento, Instituto de Biomedicina de Sevilla (IBiS), Hospital Universitario Virgen del Rocío/CSIC/Universidad de Sevilla, Seville, Spain

27 Institut d'Investigacions Biomediques August Pi i Sunyer (IDIPABS) and Centro de Investigacion en Red de Salud Mental (CIBERSAM), Barcelona, Spain

28 Institute of Neurogenetics, University of Lübeck, Lübeck, Germany

29 Child and Adolescent Mental Health Center, Mental Health Services, Capital Region of Denmark and Faculty of Health Sciences, University of Copenhagen, Copenhagen, Denmark

30 Department of Child and Adolescent Psychiatry, TU Dresden, Dresden, Germany

31 National Health Insurance Service Ilsan Hospital, Goyang-Si, South Korea

32 Youth Division, Altrecht, Institute for Mental Health, Utrecht, The Netherlands

33 Department of Neurology, Admiraal De Ruyter Ziekenhuis, Goes, The Netherlands

34 Department of Pediatrics, University of Washington, Seattle, WA, USA 


\section{Genotyping}

Genomic DNA was extracted from peripheral blood using standard protocols. Genotyping was either performed with the Illumina GoldenGate Genotyping Assay (San Diego, CA, USA) on a custom-made array containing 192 SNPs at the Genome Analysis Facility of the University Medical Center in Groningen, Netherlands (211 of the parentchild trios). The remaining 254 parent-child trios were genotyped with the Illumina HumanOmniExpressExome v1.2 BeadChip genotyping array at the Yale Center for Genomic Analysis, USA. From this array, we selected the same SNPs, as far as these were available, which was the case for 75 of the 192 SNPs; plus we selected 4 additional SNPs. This resulted in a total of 196 SNPs. See supplementary Table S2 for the sample sizes for the different SNP analyses. Processing of the raw intensity data and calling of the genotypes was performed with the Illumina GenomeStudio software (V2011.1). The PLINK input files needed for further analysis were generated using the PLINK Report Plug-in (v2.1.3) in the GenomeStudio Software.

\section{Quality control}

Quality control of the data was performed with PLINK v1.07 [29] and carried out using the recommended parameters [30]. Individuals were excluded because of (1) discordant sex information (GoldenGate Genotyping $N=13$, HumanOmniExpressExome $N=5$ ); (2) low genotyping call rate, i.e., less than $90 \%$ (GoldenGate Genotyping $N=7$, HumanOmniExpressExome $N=9$ ); (3) Mendelian errors and samples with error rates exceeding $10 \%$ (GoldenGate Genotyping $N=12$, HumanOmniExpressExome $N=8$ ), and (4) strand issues after merging data from genotyping arrays (HumanOmniExpressExome $N=19$ ). Note that removal of one parent with several affected children led to the loss of several trios, bringing the total of excluded parent-child trios after quality control check to $N=94$.

Furthermore, six SNPs not conforming to Hardy-Weinberg equilibrium or with genotyping call rate less than 90\% were excluded (GoldenGate Genotyping $N=5$, HumanOmniExpressExome $N=1$ ). Finally, after merging the SNPs from both arrays, the quality of the SNPs was assessed again and four more SNPs did not conform to Hardy-Weinberg equilibrium, reducing the number of SNPs to 186 . Considering that all members of each trio were genotyped using the same platform, no further corrections were necessary to control for possible batch effects between the two genotyped subsets.

\section{Family-based association analysis}

Family-based association analysis was carried out with the Parent-TDT option in PLINK that utilizes both the standard TDT and the parental discordance test to look for association with chronic tic disorders. Empirical significance levels were generated with PLINK using $\max (\mathrm{T})$ permutation methods with 10,000 permutations. Pointwise significance threshold was set at $\alpha=0.05$. To avoid type I errors, for the SNP-based tests, correction for multiple testing was conducted using the false discovery rate (FDR). For the gene-based analyses, all tSNPs belonging to the same gene were grouped together and were analyzed using the set-based tests in conjunction with the TDT option in PLINK. In an attempt to replicate findings of Mössner et al. [31], we also conducted a followup analysis of the TPH2 haplotype (rs4570625-rs4565946) using the haplotype-based TDT option in PLINK. Empirical $P$ values were calculated for each gene and correction for multiple testing was again done using the FDR method. Post hoc power analyses for our TDT approach were carried out with the snpPower function in the R-package Haplin v6.0.1.

To reduce the risk of type II errors, we attempted replication of our nominally significant $(P$ value $<0.05)$ SNPs against nominal significance of the case-control comparisons stemming from the TS GWAS performed by the Tourette Syndrome Association International Consortium for Genetics (TSAICG) including 1285 cases and 4964 ancestry-matched controls [6]. Given the large number of markers tested in a GWAS and accompanying stringent correction for multiple testing, GWAS studies contain a large number of SNPs with nominal significance that do not survive correction for multiple comparisons of which, however, true involvement cannot be ruled out. We argued that only SNPs that would be nominally significant in both cohorts would unequivocally point towards involvement in chronic tic disorder and then would suggest that correction for multiple testing had been too stringent. Study subjects did not overlap between TSAICG and TIC Genetics.

\section{Results}

\section{Sample description}

Of the original 465 parent-child trios (from 412 families) and 196 SNPs, a maximum of 371 parent-child trios (from 328 families; 92\% European Caucasian, 6\% Asian, and $2 \%$ Black/African American or American Indian) and 186 SNPs remained eligible for analysis following our quality control, as described earlier. Note that not all of the 186 SNPs were available for all of the families 


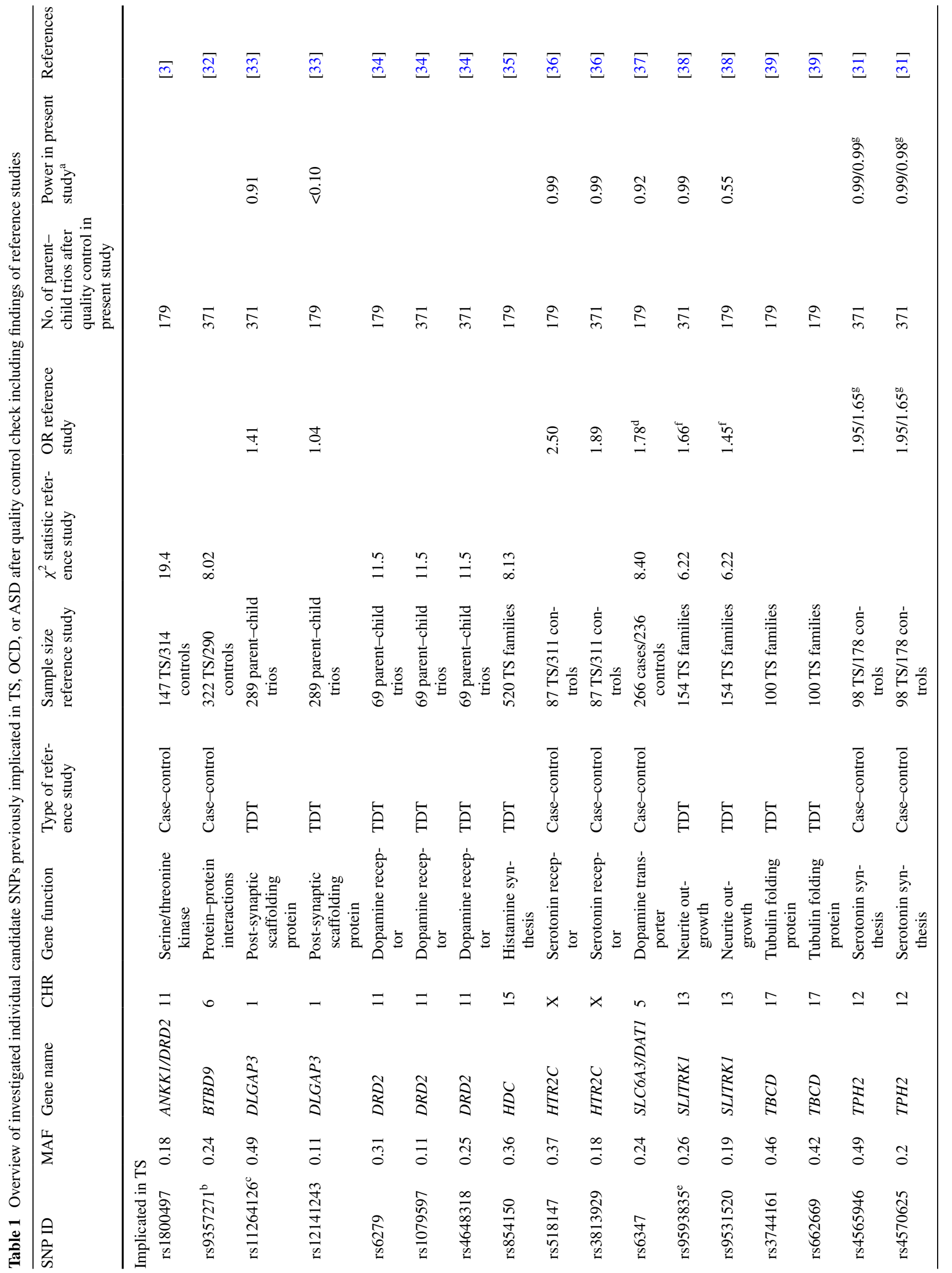




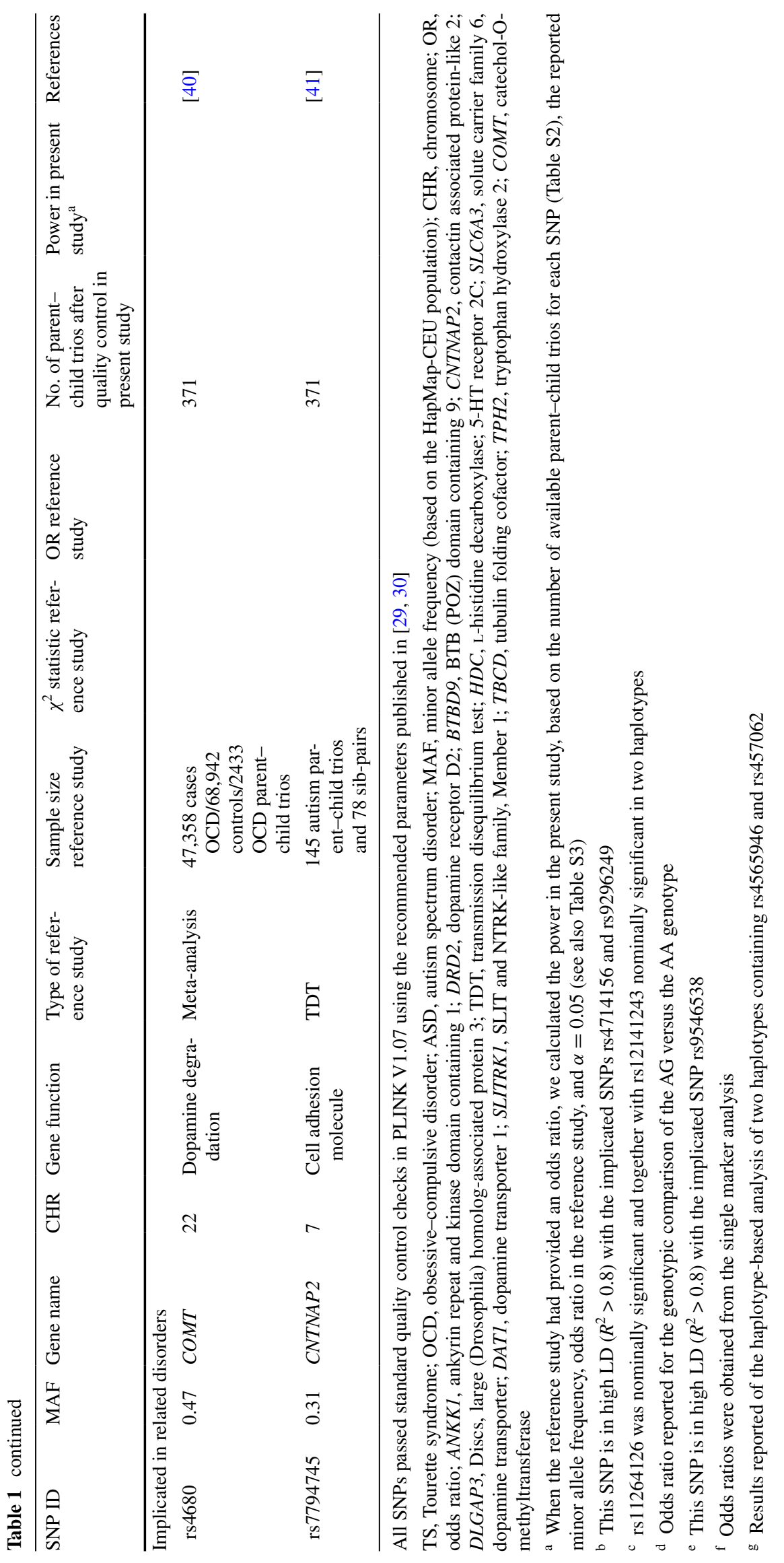


Table 2 Overview of investigated candidate genes previously implicated in TS, OCD, or ASD

\begin{tabular}{|c|c|c|c|c|c|c|c|}
\hline Gene & \# of tSNPs & $\begin{array}{l}\text { \# of tSNPs excluded } \\
\text { following } \mathrm{QC}^{\mathrm{a}}\end{array}$ & CHR & $\begin{array}{l}\text { Neurotransmitter } \\
\text { pathway }\end{array}$ & Function & $\begin{array}{l}\text { Sample size refer- } \\
\text { ence study }\end{array}$ & References \\
\hline \multicolumn{8}{|c|}{ TS neurotransmitter-related candidate genes } \\
\hline DRD2 & 14 & & 11 & Dopamine & Dopamine receptor & $147 \mathrm{TS} / 314$ controls & [3] \\
\hline$H D C$ & 11 & & 15 & Histamine & Histamine synthesis & 520 TS families & [17] \\
\hline$M A O-A$ & 9 & 1 & $\mathrm{X}$ & $\begin{array}{l}\text { Serotonin }(5-\mathrm{HT}), \\
\text { dopamine }\end{array}$ & $\begin{array}{l}\text { Degradation of } \\
\text { dopamine and } \\
\text { 5-HT }\end{array}$ & $\begin{array}{l}110 \text { TS parent-child } \\
\text { trios }\end{array}$ & {$[4]$} \\
\hline SLC6A3/DAT1 & 21 & 3 & 5 & Dopamine & $\begin{array}{l}\text { Dopamine trans- } \\
\text { porter }\end{array}$ & $\begin{array}{l}266 \text { cases } / 236 \\
\text { controls }\end{array}$ & [37] \\
\hline TPH2 & 19 & & 12 & Serotonin $(5-\mathrm{HT})$ & 5-HT synthesis & $149 \mathrm{TS} / 125$ controls & [42] \\
\hline \multicolumn{8}{|c|}{ Candidate genes implicated in related disorders } \\
\hline GABRA2 & 14 & & 4 & GABA & GABA receptor & 470 autism families & [14] \\
\hline SLC1A1 & 52 & & 9 & Glutamate & $\begin{array}{l}\text { Glutamate trans- } \\
\text { porter }\end{array}$ & 377 OCD families & {$[15]$} \\
\hline \multicolumn{8}{|c|}{ Newly investigated candidate gene } \\
\hline HRH3 & 8 & 2 & 20 & Histamine & Histamine receptor & & \\
\hline
\end{tabular}

TS, Tourette syndrome; OCD, obsessive-compulsive disorder; ASD, autism spectrum disorder; tSNPs, tagging SNPs; QC, quality check; CHR, chromosome; $D R D 2$, dopamine receptor D2; HDC, 1-histidine decarboxylase; MAO-A, monoamine oxidase-A; SLC6A3/DAT1, solute carrier family 6/dopamine transporter; $T P H 2$, tryptophan hydroxylase 2; GABRA2, GABA-A receptor, alpha 2; SLC1A1, solute carrier family 1 member 1, glutamate transporter; $H R H 3$, histamine receptor $\mathrm{H} 3$

a SNPs were excluded following standard quality control checks in PLINK V1.07 using the recommended parameters published in [29, 30]

(see Table S2); 71 SNPs were available for all 371 parent-child trios, 112 additional SNPs in 179 trios, and 3 additional SNPs in 192 trios. For an overview of the investigated SNPs and details from reference studies, see Tables 1, 2, 3 and supplementary Tables S1-2. The final set of probands with a chronic tic disorder consisted of 291 males and 80 females between 4 and 45 years of age (mean age $=13.6, \mathrm{SD}=5.80$ ). In addition to $\mathrm{TS}, 60 \%$ of the patients had OCD and $43 \%$ had ADHD.

\section{Transmission disequilibrium tests}

\section{Candidate SNPs previously implicated in TS}

None of the SNPs' $p$ values passed the FDR threshold taking multiple testing into account. However, at nominal significance $(P$ value $<0.05)$, the TDT revealed over-transmission of the minor alleles of rs3744161 and rs4565946 located in the $T B C D$ and $T P H 2$ gene, respectively (Table 4). A follow-up analysis on the TPH2 haplotype (rs4570625-rs4565946) showed no significant association with chronic tic disorders (Table S4). For the majority of the investigated SNPs, we did not find any indication for involvement at the level of nominal significance (Table S5). We did not replicate the previously implicated SLITRK1 SNPs rs9593835 and rs9531520 [38].

\section{Candidate genes previously implicated in TS or related disorders}

Similarly, for our gene-based analyses, none of our findings met the threshold for statistical significance, adjusted for multiple testing. We only found a nominally significant association for the glutamate transporter gene $S L C 1 A 1$ with chronic tic disorder $(P$ value $=0.02$, Table S6). In addition, a number of individual tSNPs from the candidate genes reached nominal significance (Table 4). SNPS previously implicated in GWAS of $T S$ and related disorders. None of these met the FDR threshold (Table S7). We found nominal significance for two top TS GWAS SNPs (Table 4), i.e., one intergenic SNP variant (rs11603305) and rs621942 of the PICALM gene $[6,7]$.

\section{Comparison of nominally significant SNPs with independent cohort}

None of our nominally significant SNPs, including the previously implicated candidate SNPs and the individual tSNPs from the candidate genes, showed a nominally significant odds ratio in the TSAICG cohort [6] (Table 4). Note that we did not compare our two nominally significant TS GWAS SNPs (rs11603305 and rs621942) as they were derived from the TSAICG cohort. 
Table 3 Overview of investigated top SNPs implicated in GWAS of TS, OCD, ADHD, or ASD

\begin{tabular}{|c|c|c|c|c|c|c|c|}
\hline$S N P$ & MAF & Gene name & CHR & Function & $\begin{array}{l}\text { Sample size reference } \\
\text { study }\end{array}$ & $\begin{array}{l}\text { No. of parent-child trios } \\
\text { after quality control in } \\
\text { present study }\end{array}$ & References \\
\hline \multicolumn{8}{|c|}{ TS GWAS SNPs } \\
\hline rs7868992 & 0.28 & COL27A1 & 9 & $\begin{array}{l}\text { Calcification of cartilage } \\
\text { and the transition of } \\
\text { cartilage to bone }\end{array}$ & 1285 cases/4964 controls & 371 & [6] \\
\hline rs621942 & 0.24 & PICALM & 11 & Endocytosis & 1894 cases/5574 controls & 192 & [7] \\
\hline rs6539267 & 0.27 & POLR3B & 12 & $\begin{array}{l}\text { DNA-dependent RNA } \\
\text { polymerase }\end{array}$ & 1285 cases/4964 controls & 371 & [6] \\
\hline rs4988462 & 0.44 & POU1F1 & 3 & Transcription factor & 2723 cases/5667 controls & 179 & [20] \\
\hline rs 7123010 & 0.27 & $M E 3$ & 11 & Malate metabolism & 1894 cases/5574 controls & & [7] \\
\hline rs $2060546^{\mathrm{a}}$ & 0.01 & & 12 & & 1894 cases/5574 controls & & [7] \\
\hline rs13063502 & 0.18 & & 3 & & 1285 cases/4964 controls & 371 & {$[6]$} \\
\hline rs769111 & 0.37 & & 7 & & 1285 cases/4964 controls & 179 & [6] \\
\hline rs 7336083 & 0.33 & & 13 & & 1285 cases/4964 controls & 371 & [6] \\
\hline rs11603305 & 0.32 & & 11 & & 1894 cases/5574 controls & 192 & [7] \\
\hline rs11149058 & 0.22 & & 13 & & 2723 cases/5667 controls & 179 & [20] \\
\hline $\mathrm{rs} 4271390^{\mathrm{a}}$ & 0.22 & & 11 & & 2723 cases/5667 controls & & [20] \\
\hline \multicolumn{8}{|c|}{ OCD GWAS SNPs } \\
\hline rs 11081062 & 0.19 & $D L G A P 1$ & 18 & Scaffold protein & $\begin{array}{l}1465 \text { cases } / 5557 \text { con- } \\
\text { trols/400 parent-child } \\
\text { trios }\end{array}$ & 371 & [21] \\
\hline rs9499708 & 0.42 & & 6 & & $\begin{array}{l}1465 \text { cases } / 5557 \text { con- } \\
\text { trols/400 parent-child } \\
\text { trios }\end{array}$ & 179 & {$[21]$} \\
\hline rs9652236 & 0.15 & & 13 & & $\begin{array}{l}1465 \text { cases } / 5557 \text { con- } \\
\text { trols } / 400 \text { parent-child } \\
\text { trios }\end{array}$ & 371 & [21] \\
\hline rs6131295 & 0.23 & & 20 & & $\begin{array}{l}1465 \text { cases } / 5557 \text { con- } \\
\text { trols/400 parent-child } \\
\text { trios }\end{array}$ & 371 & [21] \\
\hline rs $297941^{\mathrm{a}}$ & 0.44 & & 12 & & $\begin{array}{l}1465 \text { cases } / 5557 \text { con- } \\
\text { trols/400 parent-child } \\
\text { trios }\end{array}$ & & [21] \\
\hline \multicolumn{8}{|c|}{ ADHD GWAS SNPs } \\
\hline rs 2556378 & 0.18 & $B C L 11 A$ & 2 & $\begin{array}{l}\text { Myeloid and B-cell proto- } \\
\text { oncogene }\end{array}$ & 495 cases/1300 controls & 179 & [22] \\
\hline rs12575642 & 0.15 & FERMT3 & 11 & Cell adhesion & 465 trios & 371 & {$[23]$} \\
\hline rs5016282 & 0.15 & GRM5 & 11 & Glutamate receptor & 495 cases/1300 controls & 179 & {$[22]$} \\
\hline rs12037173 & 0.07 & $L R R C 7$ & 1 & $\begin{array}{l}\text { Cell adhesion, dendritic } \\
\text { branching, and neuronal } \\
\text { excitability }\end{array}$ & 465 parent-child trios & 179 & {$[23]$} \\
\hline rs11607165 & 0.15 & STIP1 & 11 & Response to stress & 465 parent-child trios & 371 & [23] \\
\hline \multicolumn{8}{|c|}{ ASD GWAS SNPs } \\
\hline rs 1718101 & 0.07 & CNTNAP2 & 7 & Cell adhesion & 2705 families & 179 & {$[24]$} \\
\hline rs4675502 & 0.37 & PARD3B & 2 & $\begin{array}{l}\text { Cell division and cell } \\
\text { polarization }\end{array}$ & 2705 families & 179 & [24] \\
\hline rs $4150167^{a}$ & 0.04 & TAF1C & 16 & Transcription factor & 2705 families & & {$[24]$} \\
\hline rs4307059 & 0.37 & & 5 & & $\begin{array}{r}780 \text { families/1204 } \\
\text { cases/6491 cases }\end{array}$ & 179 & [25] \\
\hline rs $13176113^{b}$ & 0.28 & & 5 & & $\begin{array}{r}780 \text { families/1204 } \\
\text { cases/6491 cases }\end{array}$ & 179 & {$[25]$} \\
\hline
\end{tabular}


Table 3 continued

\begin{tabular}{llllll}
\hline SNP & MAF Gene name CHR Function & $\begin{array}{l}\text { Sample size reference } \\
\text { study }\end{array}$ & $\begin{array}{l}\text { No. of parent-child trios } \\
\text { after quality control in } \\
\text { present study }\end{array}$ \\
\hline $\begin{array}{l}\text { TS GWAS SNPs } \\
\text { rs7834018 }\end{array}$ & 0.10 & 8 & & & \\
rs7711337 & 0.40 & 5 & 2705 families & 371 & {$[24]$} \\
\hline
\end{tabular}

TS, Tourette syndrome; GWAS, genome-wide association study; OCD, obsessive-compulsive disorder; ADHD, attention-deficit/hyperactivity disorder; ASD, autism spectrum disorder; MAF, minor allele frequency (based on 1000 genomes); CHR, chromosome; COL27A1, Collagen, Type XXVII, Alpha 1; PICALM, Phosphatidylinositol Binding Clathrin Assembly Protein; POLR3B, Polymerase (RNA) III (DNA Directed) Polypeptide B; POU1F1, POU Class 1 Homeobox 1; ME3, Malic Enzyme 3; DLGAP1, Discs, Large (Drosophila) Homolog-Associated Protein 1; BCL11A, B-Cell CLL/Lymphoma 11A; FERMT3, Fermitin Family Member 3; GRM5, Glutamate Receptor, Metabotropic 5; LRRC7, Leucine Rich Repeat Containing 7; STIP1, Stress-Induced Phosphoprotein 1; CNTNAP2, Contactin Associated Protein-Like 2; PARD3B, Par-3 Family Cell Polarity Regulator Beta; TAF1C, TATA Box Binding Protein (TBP)-Associated Factor

a SNP did not pass standard quality control checks in PLINK V1.07 using the recommended parameters published in [29, 30]

b Original GWAS reported results for rs7704909 that is in high LD $\left(R^{2}=1\right)$ with rs13176113

\section{Post hoc power analyses}

For those 75 SNP analyses for which we had our maximum available sample size of 371 parent-child trios, our study was sufficiently powered (power $\geq 80 \%$ ) to detect an odds ratio of 1.8 for rare SNPs $(\mathrm{MAF}=0.05)$ and an odds ratio of 1.4 for more common SNPs (MAF $\geq 0.20$; see further Table 1 and Table S3), while for those SNP analyses that were only genotyped in a subset of the trios (for most of the SNPs, $N=179$ ) our study was sufficiently powered (power $\geq 80 \%$ ) to detect common SNPs (MAF $\geq 0.20$ ) with an odds ratio of 1.6 or more (Table S3), and an $\alpha=0.05$. For all of the previously implicated candidate SNPs we did obtain the desired power of $80 \%$ except for rs 12141243 (DLGAP3) and rs9531520 (SLITRK1) (Table 1).

\section{Discussion}

The goal of this study was to provide a synthesis of previously implicated candidate SNPs, candidate genes, and top SNPs from recent GWAS of TS and related disorders. Following correction for multiple testing, we did not find evidence for involvement for the previously implicated neurotransmitter-related candidate genes (DRD2, HDC, MAO-A, SLC6A3/DAT1, TPH2, COMT, GABRA2, SLC1A1, and $H R H 3)$, SNPs previously implicated in candidate genes (BTBD9, CNTNAP2, DLGAP3, SLITRK1, and TBCD), and top SNPs from GWAS of TS and related disorders. We also did not find evidence for the top five LD-independent SNPs from the first GWAS of TS [6] and the SLITRK1 candidate gene [38]. This non-replication of candidate genes is in line with findings in other neuropsychiatric disorders [43, 44].

Both pharmacological evidence and neuroimaging studies have pointed towards involvement of the dopamine pathway, and based on these findings several groups have investigated genes within this pathway, mostly with inconsistent results [2]. Included in our study are the dopamine receptor $D 2(D R D 2)$ and the dopamine transporter (SLC6A3/DAT1) gene that were both implicated in TS by others [3, 34, 37] and the catechol-O-methyltransferase (COMT) gene that was implicated in OCD [45], a related disorder. Our findings for the DRD2 gene are in contrast with the findings of Herzberg et al. and Comings et al. $[3,34]$ as both our investigation of previously implicated SNPs (rs1800497, rs6279, rs1079597, and rs4648318) and our analysis of the entire gene yielded no significant association. The differences in findings could be due to our increased sample size, as both previous studies included less than 150 cases [3, 34]. Similarly, we did not find evidence for $S L C 6 A 3$, as both our analysis of a previously implicated SNP (rs6347) [37] and our analysis of the entire gene showed no association with chronic tic disorder. This discrepancy might be explained by the use of different analytical approaches, as Yoon et al. employed a case-control analysis. Finally, we found no evidence for the COMT SNP rs4680; however, this gene has never been associated with chronic tic disorders before but is strongly implicated in OCD [45].

Serotonin is another well-studied neurotransmitter pathway. Studies have shown a reduced concentration of serotonin and its metabolite in the brain and cerebrospinal fluid of TS patients [5]. Included in our study were SNPs in genes belonging to the serotonin receptor $H T R 2 C$, monoamine oxidase-A (MAO-A), and the tryptophan hydroxylase 2 (TPH2) gene, of which the latter is responsible for the synthesis of serotonin in the brain [31]. In contrast to the findings of Dehning et al. [36], we found no evidence for the HTR2C SNPs rs3813929 and rs518147. With regard to THP2, both previously implicated SNPs (rs4565946 and 


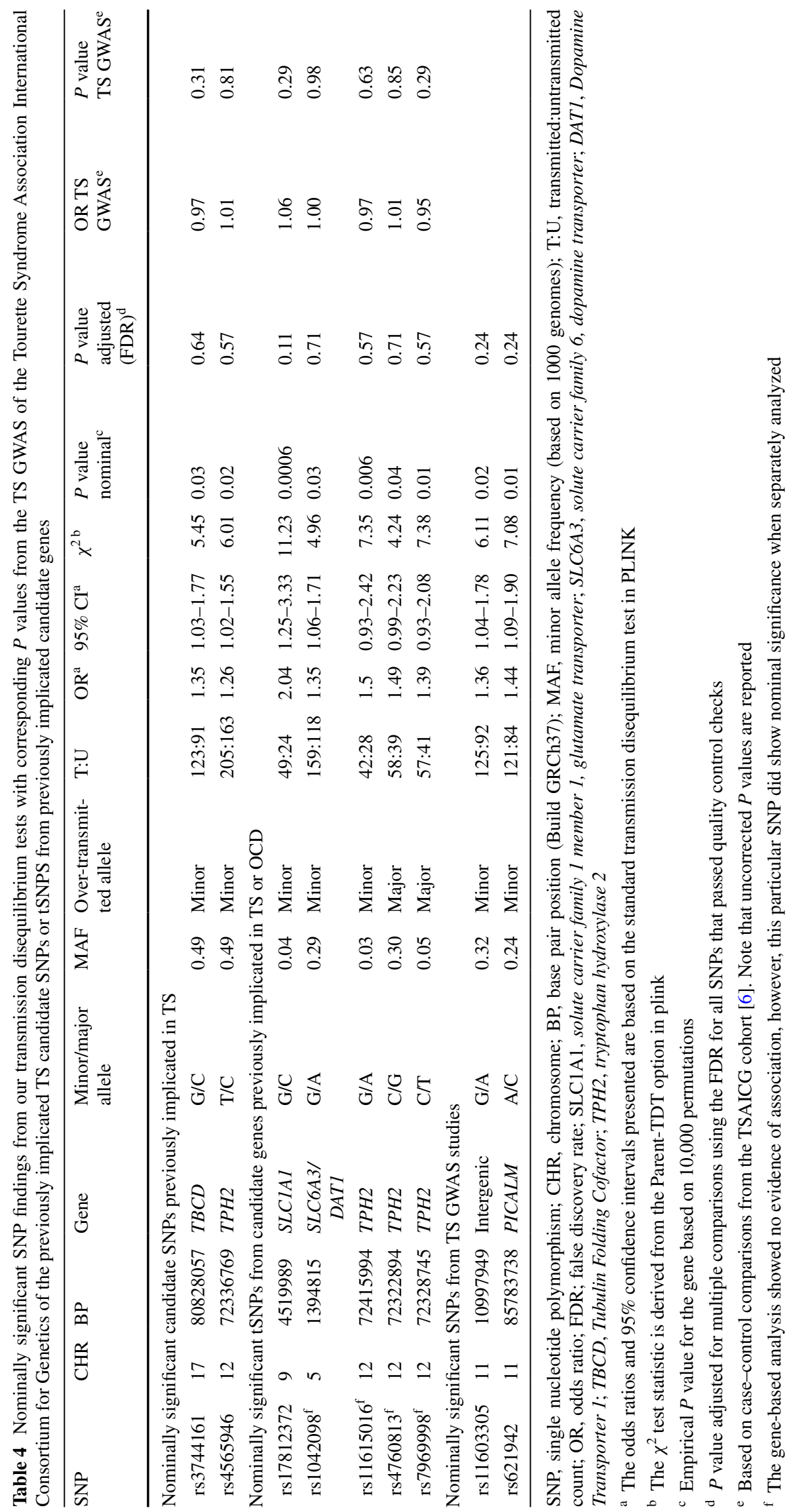


rs4570625) [31, 42] showed no evidence for association, although rs4565946 indicated a weak nominally significant signal that did not pass the threshold for significance when corrected for multiple testing. Further investigation of the THP2 gene in our gene-based analysis and haplotype-based analysis of the haplotype rs4570625-rs4565946 showed no evidence for association. MAO-A is a well-known neurotransmitter gene that is responsible for both the degradation of serotonin and dopamine [2] and while the MAO-A promoter variable number of tandem repeats polymorphism was previously implicated in TS by Díaz-Anzaldúa et al. [4], MAO-A SNPs were not implicated in our study.

Following the finding of Ercan-Sencicek et al. of a rare mutation in the Histidine Decarboxylase (HDC) gene in a TS family, the histamine pathway has garnered much interest $[17,35,46]$. $H D C$ encodes for a gene necessary for the synthesis of histamine, that functions as a neurotransmitter but is also involved in gastric acid secretion, immune system, bronchoconstriction, and vasodilation $[17,35]$. However, we did not find a significant association for the $H D C$ candidate gene or the previously implicated HDC SNP rs854150; this is in contrast with several studies $[17,35,46]$, but is consistent with the finding of others $[6,47,48]$. We further investigated the histamine pathway by investigating another pathway gene that was not previously investigated in relation to chronic tic disorders: the histamine receptor $\mathrm{H} 3$ (HRH3) gene. Here, we also found no association between this gene and chronic tic disorders. Considering that the initial $H D C$ mutation is extremely rare [17] and that TS is considered a heterogeneous disorder [2], it is therefore likely that variants in the $H D C$ gene, or in a broader sense variants in the histamine pathway, only cause tics in a subset of chronic tic cases.

Glutamate and gamma-aminobutyric acid (GABA) are major neurotransmitter pathways that may play a role in TS [5]. Glutamate and GABA play opposing roles as important excitatory and inhibitory neurotransmitter pathways in the central nervous system, respectively [2]. We did not find associations between chronic tic disorders and the glutamate transporter (SLCIAI) gene that has been implicated in OCD [15], or the GABA-A receptor, alpha 2 (GABRA2) gene that has been implicated in autism [14].

Moving away from neurotransmitter pathways, there is a growing body of literature [2] implicating SNPs in candidate genes with a more structural function such as: the BTB domain containing 9 (BTBD9), contactin associated protein-like 2 (CNTNAP2), discs large homologassociated protein 3 (DLGAP3), SLIT and NTRK-like family member 1 (SLITRK1), and the tubulin folding cofactor $D(T B C D)$ gene [39]. We found no evidence for an association between SNPs in these genes and chronic tic disorders. SLITRK1 is the most-studied gene and is functionally involved in neurite outgrowth [2]. We were unable to replicate the SLITRK1 SNPs rs9593835 and rs9531520 which is in line with most TS studies [49-53], but not others [38, 54, 55]. Because of the inconsistent results in the past, there is an ongoing discussion whether de novo or transmitted SLITRKI variants contribute to TS [52]. Our findings do not support an association.

Further, our study was unable to demonstrate associations between chronic tic disorders and previously implicated SNPs from GWAS of TS, OCD, ADHD, and ASD $[6,7,20-25]$. Particularly, we found no associations for the top five LD-independent SNPs from the first GWAS of TS [6], including the top signal (rs7868992). Unfortunately, one of the top GWAS SNPs (rs2060546) did not pass standard quality controls checks, an SNP closest to NTN4, an axon guidance molecule expressed in developing striatum that was recently replicated by Paschou et al. [7].

A strength of our study is the well-characterized sample of parent-child trios. Use of TDT analysis eliminated population stratification bias, a major advantage over classical case-control studies [11]. Our post hoc power analyses demonstrated that, based on reported effect sizes, our study was sufficiently powered to detect associations for most of the previously implicated TS candidate SNPs. However, this was not the case for one of the candidate SNPs from SLITRK1 and one from DLGAP3. As another strength, we used the large TSAICG case-control study [6] as a comparison sample of our nominally significant findings. A limitation of TDT is that only the heterozygous parents are informative. SNP loci that are less polymorphic are not optimally studied by this method. Importantly, it should also be noted that our study focused solely on SNPs rather than rare copy number variations (CNVs) or repeat polymorphisms. Thus, non-significant genes such as $M A O-A$ and $C O M T$ may still play a role in TS through these other variant types $[16,56]$. Our study also does not rule out that the investigated genes could still be involved in gene-gene interactions and gene-environment interactions or through rare mutations that can only be revealed through targeted re-sequencing [57]. For example, Alexander et al. found four deleterious mutations in the SLITRK1 gene and one deleterious mutation in the $H D C$ gene [57]. Finally, while we attempted to include as many candidate genes and SNPs available with promising evidence, we are aware that our selection does not include every single SNP implicated by previous studies. However, we believe that our selection is a good representation of the most important candidate genes and SNPs in the TS literature, as reviewed in [2].

In conclusion, following corrections for multiple testing, our TDT study did not show statistically significant 
associations between chronic tic disorders and previously implicated SNPs and tSNPs within neurotransmitter-related candidate genes. Moreover, our nominally significant findings were not replicated in an independent cohort. This highlights the importance of exceptional caution in interpreting results from previous SNP-based candidate gene studies. The efforts in discovering genetic loci involved in TS etiology are comparable to other neuropsychiatric disorders where candidate gene studies have also shown non-replication across studies [43, 44]. Similar to conditions such as ASD [14], the genetic architecture of TS likely involves complex and heterogeneous inheritance of both common and rare variants in many different genes and biological pathways. Genome-wide studies of large cohorts that capture all of these types of variation and targeted re-sequencing efforts to detect rare mutations (also addressing candidate genes) could be better suited for studying the complex neurobiology of TS and chronic tic disorders. Also the use of polygenic risk scores could further enhance understanding the relevance of common TS-related SNPs [20]. Meta-analytic studies are currently underway that may further clarify or rule out the possible involvement of the candidate genes $T B C D$, TPH2, SLC1A1, and SLC6A3, and SNPs from GWAS studies, i.e., the intergenic SNP variant rs11603305 and rs621942 of the PICALM gene which were all nominally significant in our study.

Acknowledgements We are extremely thankful to the families who participated in this study. We are grateful to NJCTS for facilitating the inception and organization of the TIC Genetics study. We are also grateful to Dongmei Yu and the Tourette Syndrome Association International Consortium for Genetics (TSAICG) for access to the TS GWAS summary data. We also like to thank all of the individuals involved in recruitment and assessment of the subjects reported in this study: Denmark: Heidi B. Biernat, Nikoline Frost, Julie Hagstrøm (Copenhagen); Germany: Benjamin Bodmer, Mareen Czekalla, Yvonne Friedrich, (Dresden); Daniela, Ihlrenburg-Schwarz (Hannover); Julia Bohnenpoll, Jenny Schmalfeld (Lübeck); Ariane Saccarello (Ulm); Spain: María T. Cáceres, Fátima Carrillo, Marta Correa (Sevilla); The Netherlands: Andreas Lamerz, Noor Tromp (Alkmaar); Vivian op de Beek, Annelieke Hagen (Amsterdam); Jolanda Blom, Rudi Bruggemans, MariAnne Overdijk (Barendrecht); Marieke Messchendorp, Thaïra Openneer, Deborah Sival, Anne-Marie Stolte (Groningen); Nadine Schalk (Nijmegen); Sebastian F.T.M. de Bruijn, Judith J.G. Rath (The Hague); UK: Anup Kharod (London); USA: Sarah Jacobson (Cincinnati); Angie Cookman (Iowa City); Zoey Shaw (Mount Sinai/NKI); Shannon Granillo, Jasdeep Sandhu (Seattle Children's); and to all who may not have been mentioned.

Funding This study was supported by grants from the National Institute of Mental Health (R01MH092290 to LWB; R01MH092291 to SK; R01MH092292 to BJC; R01MH092293 to GAH and JAT; R01MH092513 to SHZ; R01MH092516 to DEG; R01MH092520 DLG; R01MH092289 to MWS; K08MH099424 to TVF) and NJCTS (NJ Center for Tourette Syndrome and Associated Disorders; to GAH and JAT). We also thank the NIMH Repository and Genomics Resource (U24MH068457 to JAT) at RUCDR Infinite Biologics for transforming cell lines and providing DNA samples. The content is solely the responsibility of the authors and does not necessarily represent the official views of the National Institutes of Health. This work was additionally supported by grants from Spain (to PM): the Instituto de Salud Carlos III (PI10/01674, PI13/01461), the Consejería de Economía, Innovación, Ciencia y Empresa de la Junta de Andalucía (CVI-02526, CTS-7685), the Consejería de Salud y Bienestar Social de la Junta de Andalucía (PI-0741/2010, PI-0437-2012, PI-04712013), the Sociedad Andaluza de Neurología, the Fundación Alicia Koplowitz, the Fundación Mutua Madrileña and the Jaques and Gloria Gossweiler Foundation; grants from Germany (to AM): Deutsche Forschungsgemeinschaft (DFG: MU 1692/3-1, MU 1692/4-1 and Project C5 of the SFB 936). This research was also supported in part by an Informatics Starter Grant from the PhRMA Foundation (to YB). None of the study sponsors were involved in the study design; in the collection, analysis and interpretation of the data; in the writing of the report; and in the decision to submit the paper for publication.

Author Contributions MA, GAH, PJH, and AD were involved in the organization, design, and execution of the research project, and together with DL and DG were involved in the critique of the statistical analysis; MA wrote the first draft of the manuscript, which was critically reviewed by JAT, GAH, PJH, and AD who were also involved in the conception of the research project. AGL was involved in the recruitment of participants. The following authors were involved in the review, critique of the manuscript, and recruitment of participants: DL, DG, TVF, LWB, KC., BJC, LE, CF, OF, BG, DLG, DEG, TH., IH, HJH, CH, LI, EJ, YKK, YSK, YJK, SDK, SK, BL, MG, AM (Maras), PB, AM (Morer), KMV, AM (Münchau), TLM, KJP, VR, EYS, DHS, JS, AS, JT, EB, FV, SW, MW, SHZ, RAK. All authors have approved the final article.

\section{Compliance with ethical standards}

Conflict of interest Dr. Gilbert has received honoraria from the Tourette Syndrome Association/Centers for Disease Control and Prevention and the American Academy of Pediatrics; has received book royalties from Elsevier, and one-time consulting fees for clinical trial design from Teva/Auspex pharmaceuticals, and has received compensation for expert testimony for the U.S. D.O.J. D.V.I.C. program. Dr. Gilbert has also received research support from Ecopipam Pharmaceuticals (clinical trial, Tourette Syndrome). Dr. Maras is a speaker, consultant for Lilly, Neurim, and Janssen. Dr. Roessner has received payment for consulting and writing activities from Lilly, Novartis, and Shire Pharmaceuticals, lecture honoraria from Lilly, Novartis, Shire Pharmaceuticals, Actelion and Medice Pharma, and support for research from Shire and Novartis. He has carried out clinical trials in cooperation with the Novartis, Shire, and Otsuka companies. The following authors reported no biomedical financial interests or potential conflicts of interest: Mohamed Abdulkadir, Douglas Londono, Derek Gordon, Thomas V. Fernandez, Lawrence W. Brown, Keun-Ah Cheon, Barbara J. Coffey, Lonneke Elzerman, Carolin Fremer, Odette Fründt, Blanca Garcia-Delgar, Dorothy E. Grice, Tammy Hedderly, Isobel Heyman, Hyun Ju Hong, Chaim Huyser, Laura Ibanez-Gomez, Ewgeni Jakubovski, Young Key Kim, Young Shin Kim, Yun-Joo Koh, Sodahm Kook, Samuel Kuperman, Bennett Leventhal, Andrea G. Ludolph, Marcos Madruga-Garrido, Pablo Mir, Astrid Morer, Kirsten Müller-Vahl, Alexander Münchau, Tara L. Murphy, Kerstin J. Plessen, Eun-Young Shin, Dong-Ho Song, Jungeun Song, Jennifer Tübing, Els van den Ban, Frank Visscher, Sina Wanderer, Martin Woods, Samuel H. Zinner, Robert A. King, Jay A. Tischfield, Gary A. Heiman, Pieter J. Hoekstra, and Andrea Dietrich.

Open Access This article is distributed under the terms of the Creative Commons Attribution 4.0 International License (http:// 
creativecommons.org/licenses/by/4.0/), which permits unrestricted use, distribution, and reproduction in any medium, provided you give appropriate credit to the original author(s) and the source, provide a link to the Creative Commons license, and indicate if changes were made.

\section{References}

1. O'Rourke JA, Scharf JM, Yu D, Pauls DL (2009) The genetics of Tourette syndrome: a review. J Psychosom Res 67:533-545

2. Paschou P (2013) The genetic basis of Gilles de la Tourette Syndrome. Neurosci Biobehav Rev 37:1026-1039

3. Comings DE, Comings BG, Muhleman D, Dietz G, Shahbahrami B, Tast D, Knell E, Kocsis P, Baumgarten R, Kovacs BW (1991) The dopamine D2 receptor locus as a modifying gene in neuropsychiatric disorders. JAMA 266:1793-1800

4. Díaz-Anzaldúa A, Joober R, Rivière J-B, Dion Y, Lespérance P, Richer F, Chouinard S, Rouleau GA (2004) Tourette syndrome and dopaminergic genes: a family-based association study in the French Canadian founder population. Mol Psychiatry 9:272-277

5. Felling RJ, Singer HS (2011) Neurobiology of Tourette syndrome: current status and need for further investigation. J Neurosci 31:12387-12395

6. Scharf JM, Yu D, Mathews CA, Neale BM, Stewart SE, Fagerness JA, Evans P, Gamazon E, Edlund CK, Service SK, Tikhomirov A, Osiecki L, Illmann C, Pluzhnikov A, Konkashbaev A, Davis LK, Han B, Crane J, Moorjani P, Crenshaw AT, Parkin MA, Reus VI, Lowe TL, Rangel-Lugo M, Chouinard S, Dion Y, Girard S, Cath DC, Smit JH, King RA, Fernandez T V, Leckman JF, Kidd KK, Kidd JR, Pakstis AJ, State MW, Herrera LD, Romero R, Fournier E, Sandor P, Barr CL, Phan N, Gross-Tsur V, Benarroch F, Pollak Y, Budman CL, Bruun RD, Erenberg G, Naarden AL, Lee PC, Weiss N, Kremeyer B, Berrío GB, Campbell DD, Cardona Silgado JC, Ochoa WC, Mesa Restrepo SC, Muller H, Valencia Duarte AV, Lyon GJ, Leppert M, Morgan J, Weiss R, Grados MA, Anderson K, Davarya S, Singer H, Walkup J, Jankovic J, Tischfield JA, Heiman GA, Gilbert DL, Hoekstra PJ, Robertson MM, Kurlan R, Liu C, Gibbs JR, Singleton A, Hardy J, Strengman E, Ophoff RA, Wagner M, Moessner R, Mirel DB, Posthuma D, Sabatti C, Eskin E, Conti D V, Knowles JA, Ruiz-Linares A, Rouleau GA, Purcell S, Heutink P, Oostra BA, McMahon WM, Freimer NB, Cox NJ, Pauls DL (2013) Genome-wide association study of Tourette's syndrome. Mol Psychiatry 18:721-728

7. Paschou P, Yu D, Gerber G, Evans P, Tsetsos F, Davis LK, Karagiannidis I, Chaponis J, Gamazon E, Mueller-Vahl K, Stuhrmann M, Schloegelhofer M, Stamenkovic M, Hebebrand J, Noethen M, Nagy P, Barta C, Tarnok Z, Rizzo R, Depienne C, Worbe Y, Hartmann A, Cath DC, Budman CL, Sandor P, Barr C, Wolanczyk T, Singer H, Chou I-C, Grados M, Posthuma D, Rouleau GA, Aschauer H, Freimer NB, Pauls DL, Cox NJ, Mathews CA, Scharf JM (2014) Genetic association signal near NTN4 in Tourette syndrome. Ann Neurol 76:310-315

8. Liu S, Yu X, Xu Q, Cui J, Yi M, Zhang X, Ge Y, Ma X (2015) Support of positive association in family-based genetic analysis between COL27A1 and Tourette syndrome. Sci Rep 5:12687

9. Robertson MM, Eapen V, Singer HS, Martino D, Scharf JM, Paschou P, Roessner V, Woods DW, Hariz M, Mathews CA, Črnčec R, Leckman JF (2017) Gilles de la Tourette syndrome. Nat Rev Dis Prim 3:16097

10. Dietrich A, Fernandez TV, King RA, State MW, Tischfield JA, Hoekstra PJ, Heiman GA, TIC Genetics Collaborative Group (2015) The Tourette International Collaborative Genetics (TIC Genetics) study, finding the genes causing Tourette syndrome: objectives and methods. Eur Child Adolesc Psychiatry $24: 141-151$

11. Spielman RS, McGinnis RE, Ewens WJ (1993) Transmission test for linkage disequilibrium: the insulin gene region and insulin-dependent diabetes mellitus (IDDM). Am J Hum Genet 52:506-516

12. Heiman GA, King RA, Tischfield JA (2008) New Jersey Center for Tourette Syndrome sharing repository: methods and sample description. BMC Med Genomics 1:58

13. American Psychiatric Association (2000) Diagnostic and Statistical Manual of Mental Disorders, 4th Edition, Text Revision (DSM-IV-TR). American Psychiatric Association, Arlington

14. Ma DQ, Whitehead PL, Menold MM, Martin ER, Ashley-Koch AE, Mei H, Ritchie MD, Delong GR, Abramson RK, Wright HH, Cuccaro ML, Hussman JP, Gilbert JR, Pericak-Vance MA (2005) Identification of significant association and gene-gene interaction of GABA receptor subunit genes in autism. Am J Hum Genet 77:377-388

15. Samuels J, Wang Y, Riddle MA, Greenberg BD, Fyer AJ, McCracken JT, Rauch SL, Murphy DL, Grados MA, Knowles JA, Piacentini J, Cullen B, Bienvenu OJ, Rasmussen SA, Geller D, Pauls DL, Liang K-Y, Shugart YY, Nestadt G (2011) Comprehensive family-based association study of the glutamate transporter gene SLC1A1 in obsessive-compulsive disorder. Am J Med Genet B 156B:472-477

16. Fernandez TV, Sanders SJ, Yurkiewicz IR, Ercan-Sencicek AG, Kim Y-S, Fishman DO, Raubeson MJ, Song Y, Yasuno K, Ho WSC, Bilguvar K, Glessner J, Chu SH, Leckman JF, King RA, Gilbert DL, Heiman GA, Tischfield JA, Hoekstra PJ, Devlin B, Hakonarson H, Mane SM, Günel M, State MW (2012) Rare copy number variants in tourette syndrome disrupt genes in histaminergic pathways and overlap with autism. Biol Psychiatry 71:392-402

17. Ercan-Sencicek AG, Bilguvar K, Roak BJO, Ph D, Mason CE, Abbott T, Gupta A, King RA, Pauls DL, Tischfield JA, Heiman GA, Singer HS, Gilbert DL, Hoekstra PJ, Morgan TM, Loring E, Yasuno K, Fernandez T, Sanders S, Louvi A, Cho JH, Mane S, Colangelo CM, Biederer T, Lifton RP, Gunel M, State MW (2010) L-histidine decarboxylase and Tourette's syndrome. N Engl J Med 362:1901-1908

18. International $\mathrm{T}$, Consortium $\mathrm{H}$ (2003) The international HapMap project. Nature 426:789-796

19. Barrett JC, Fry B, Maller J, Daly MJ (2005) Haploview: analysis and visualization of $\mathrm{LD}$ and haplotype maps. Bioinformatics 21:263-265

20. Yu D, Mathews CA, Scharf JM, Neale BM, Davis LK, Gamazon ER, Derks EM, Evans P, Edlund CK, Crane J, Fagerness JA, Osiecki L, Gallagher P, Gerber G, Haddad S, Illmann C, McGrath LM, Mayerfeld C, Arepalli S, Barlassina C, Barr CL, Bellodi L, Benarroch F, Berrió GB, Bienvenu OJ, Black DW, Bloch MH, Brentani H, Bruun RD, Budman CL, Camarena B, Campbell DD, Cappi C, Silgado JCC, Cavallini MC, Chavira DA, Chouinard S, Cook EH, Cookson MR, Coric V, Cullen B, Cusi D, Delorme R, Denys D, Dion Y, Eapen V, Egberts K, Falkai P, Fernandez T, Fournier E, Garrido H, Geller D, Gilbert DL, Girard SL, Grabe HJ, Grados MA, Greenberg BD, Gross-Tsur V, Grünblatt E, Hardy J, Heiman GA, Hemmings SMJ, Herrera LD, Hezel DM, Hoekstra PJ, Jankovic J, Kennedy JL, King RA, Konkashbaev AI, Kremeyer B, Kurlan R, Lanzagorta N, Leboyer M, Leckman JF, Lennertz L, Liu C, Lochner C, Lowe TL, Lupoli S, Macciardi F, Maier W, Manunta P, Marconi M, McCracken JT, Mesa Restrepo SC, Moessner R, Moorjani P, Morgan J, Muller H, Murphy DL, Naarden AL, Nurmi E, Ochoa WC, Ophoff RA, Pakstis AJ, Pato MT, Pato CN, Piacentini J, Pittenger C, Pollak Y, Rauch SL, Renner T, Reus VI, Richter MA, Riddle MA, Robertson MM, Romero R, Rosário MC, Rosenberg D, 
Ruhrmann S, Sabatti C, Salvi E, Sampaio AS, Samuels J, Sandor P, Service SK, Sheppard B, Singer HS, Smit JH, Stein DJ, Strengman E, Tischfield JA, Turiel M, Valencia Duarte AV, Vallada H, Veenstra-VanderWeele J, Walitza S, Wang Y, Weale M, Weiss R, Wendland JR, Westenberg HGM, Shugart YY, Hounie AG, Miguel EC, Nicolini H, Wagner M, Ruiz-Linares A, Cath DC, McMahon W, Posthuma D, Oostra BA, Nestadt G, Rouleau GA, Purcell S, Jenike MA, Heutink P, Hanna GL, Conti D V., Arnold PD, Freimer NB, Stewart SE, Knowles JA, Cox NJ, Pauls DL (2015) Cross-Disorder Genome-Wide Analyses Suggest a Complex Genetic Relationship Between Tourette's Syndrome and OCD. Am J Psychiatry 172:82-93

21. Stewart SE, Yu D, Scharf JM, Neale BM, Fagerness JA, Mathews CA, Arnold PD, Evans PD, Gamazon ER, Davis LK, Osiecki L, McGrath L, Haddad S, Crane J, Hezel D, Illman C, Mayerfeld C, Konkashbaev A, Liu C, Pluzhnikov A, Tikhomirov A, Edlund CK, Rauch SL, Moessner R, Falkai P, Maier W, Ruhrmann S, Grabe H-J, Lennertz L, Wagner M, Bellodi L, Cavallini MC, Richter MA, Cook EH, Kennedy JL, Rosenberg D, Stein DJ, Hemmings SMJ, Lochner C, Azzam A, Chavira DA, Fournier E, Garrido H, Sheppard B, Umaña P, Murphy DL, Wendland JR, Veenstra-VanderWeele J, Denys D, Blom R, Deforce D, Van Nieuwerburgh F, Westenberg HGM, Walitza S, Egberts K, Renner T, Miguel EC, Cappi C, Hounie AG, Conceição do Rosário M, Sampaio AS, Vallada H, Nicolini H, Lanzagorta N, Camarena B, Delorme R, Leboyer M, Pato CN, Pato MT, Voyiaziakis E, Heutink P, Cath DC, Posthuma D, Smit JH, Samuels J, Bienvenu OJ, Cullen B, Fyer AJ, Grados MA, Greenberg BD, McCracken JT, Riddle MA, Wang Y, Coric V, Leckman JF, Bloch M, Pittenger C, Eapen V, Black DW, Ophoff RA, Strengman E, Cusi D, Turiel M, Frau F, Macciardi F, Gibbs JR, Cookson MR, Singleton A, Hardy J, Crenshaw AT, Parkin MA, Mirel DB, Conti DV, Purcell S, Nestadt G, Hanna GL, Jenike MA, Knowles JA, Cox N, Pauls DL (2013) Genome-wide association study of obsessive-compulsive disorder. Mol Psychiatry 18:788-798

22. Hinney A, Scherag A, Jarick I, Albayrak Ö, Pütter C, Pechlivanis S, Dauvermann MR, Beck S, Weber H, Scherag S, Nguyen TT, Volckmar A-L, Knoll N, Faraone SV, Neale BM, Franke B, Cichon S, Hoffmann P, Nöthen MM, Schreiber S, Jöckel K-H, Wichmann H-E, Freitag C, Lempp T, Meyer J, Gilsbach S, Herpertz-Dahlmann B, Sinzig J, Lehmkuhl G, Renner TJ, Warnke A, Romanos M, Lesch K-P, Reif A, Schimmelmann BG, Hebebrand J (2011) Genome-wide association study in German patients with attention deficit/hyperactivity disorder. Am J Med Genet B 156B:888-897

23. Mick E, McGough J, Loo S, Doyle AE, Wozniak J, Wilens TE, Smalley S, McCracken J, Biederman J, Faraone SV (2011) Genome-wide association study of the child behavior checklist dysregulation profile. J Am Acad Child Adolesc Psychiatry 50:807-817

24. Anney R, Klei L, Pinto D, Almeida J, Bacchelli E, Baird G, Bolshakova N, Bölte S, Bolton PF, Bourgeron T, Brennan S, Brian J, Casey J, Conroy J, Correia C, Corsello C, Crawford EL, de Jonge M, Delorme R, Duketis E, Duque F, Estes A, Farrar P, Fernandez BA, Folstein SE, Fombonne E, Gilbert J, Gillberg C, Glessner JT, Green A, Green J, Guter SJ, Heron EA, Holt R, Howe JL, Hughes G, Hus V, Igliozzi R, Jacob S, Kenny GP, Kim C, Kolevzon A, Kustanovich V, Lajonchere CM, Lamb JA, Law-Smith M, Leboyer M, Le Couteur A, Leventhal BL, Liu X-Q, Lombard F, Lord C, Lotspeich L, Lund SC, Magalhaes TR, Mantoulan C, McDougle CJ, Melhem NM, Merikangas A, Minshew NJ, Mirza GK, Munson J, Noakes C, Nygren G, Papanikolaou K, Pagnamenta AT, Parrini B, Paton T, Pickles A, Posey DJ, Poustka F, Ragoussis J, Regan R, Roberts W, Roeder K, Roge B, Rutter ML, Schlitt S, Shah N, Sheffield VC, Soorya L, Sousa I, Stoppioni V, Sykes N, Tancredi
R, Thompson AP, Thomson S, Tryfon A, Tsiantis J, Van Engeland H, Vincent JB, Volkmar F, Vorstman JAS, Wallace S, Wing K, Wittemeyer K, Wood S, Zurawiecki D, Zwaigenbaum L, Bailey AJ, Battaglia A, Cantor RM, Coon H, Cuccaro ML, Dawson G, Ennis S, Freitag CM, Geschwind DH, Haines JL, Klauck SM, McMahon WM, Maestrini E, Miller J, Monaco AP, Nelson SF, Nurnberger JI, Oliveira G, Parr JR, PericakVance MA, Piven J, Schellenberg GD, Scherer SW, Vicente AM, Wassink TH, Wijsman EM, Betancur C, Buxbaum JD, Cook EH, Gallagher L, Gill M, Hallmayer J, Paterson AD, Sutcliffe JS, Szatmari P, Vieland VJ, Hakonarson H, Devlin B (2012) Individual common variants exert weak effects on the risk for autism spectrum disorders. Hum Mol Genet 21:4781-4792

25. Wang K, Zhang H, Ma D, Bucan M, Glessner JT, Abrahams BS, Salyakina D, Imielinski M, Bradfield JP, Sleiman PMA, Kim CE, Hou C, Frackelton E, Chiavacci R, Takahashi N, Sakurai T, Rappaport E, Lajonchere CM, Munson J, Estes A, Korvatska O, Piven J, Sonnenblick LI, Alvarez Retuerto AI, Herman EI, Dong H, Hutman T, Sigman M, Ozonoff S, Klin A, Owley T, Sweeney JA, Brune CW, Cantor RM, Bernier R, Gilbert JR, Cuccaro ML, McMahon WM, Miller J, State MW, Wassink TH, Coon H, Levy SE, Schultz RT, Nurnberger JI, Haines JL, Sutcliffe JS, Cook EH, Minshew NJ, Buxbaum JD, Dawson G, Grant SFA, Geschwind DH, Pericak-Vance MA, Schellenberg GD, Hakonarson H (2009) Common genetic variants on 5p14.1 associate with autism spectrum disorders. Nature 459:528-533

26. Bertelsen B, Stefánsson H, Jensen LR, Melchior L, Debes NM, Groth C, Skov L, Werge T, Karagiannidis I, Tarnok Z, Barta C, Nagy P, Farkas L, Brøndum-nielsen K, Rizzo R, Gulisano M, Rujescu D, Kiemeney LA, Tosato S, Nawaz S, Ingason A, Unnsteinsdottir U, Steinberg S, Ludvigsson P, Stefansson K, Kuss AW, Paschou P, Cath D, Hoekstra PJ, Müller-vahl K, Stuhrmann M, Silahtaroglu A, Pfundt R, Tümer Z (2016) Archival Report Association of AADAC deletion and Gilles de la Tourette syndrome in a large European cohort. Biol Psychiatry 79:383-391

27. Huertas-Fernández I, Gómez-Garre P, Madruga-Garrido M, Bernal-Bernal I, Bonilla-Toribio M, Martín-Rodríguez JF, CáceresRedondo MT, Vargas-González L, Carrillo F, Pascual A, Tischfield JA, King RA, Heiman GA, Mir P (2015) GDNF gene is associated with tourette syndrome in a family study. Mov Disord 30:1115-1120

28. Tsetsos F, Padmanabhuni SS, Alexander J, Karagiannidis I, Tsifintaris M, Topaloudi A, Mantzaris D, Georgitsi M, Drineas P, Paschou P (2016) Meta-analysis of Tourette syndrome and attention deficit hyperactivity disorder provides support for a shared genetic basis. Front Genet 10:1-7

29. Purcell S, Neale B, Todd-Brown K, Thomas L, Ferreira MAR, Bender D, Maller J, Sklar P, de Bakker PIW, Daly MJ, Sham PC (2007) PLINK: a tool set for whole-genome association and population-based linkage analyses. Am J Hum Genet 81:559-575

30. Anderson CA, Pettersson FH, Clarke GM, Cardon LR, Morris AP, Zondervan KT (2010) Data quality control in genetic casecontrol association studies. Nat Protoc 5:1564-1573

31. Mössner R, Müller-Vahl KR, Döring N, Stuhrmann M (2007) Role of the novel tryptophan hydroxylase- 2 gene in Tourette syndrome. Mol Psychiatry 12:617-619

32. Rivière J-B, Xiong L, Levchenko A, St-Onge J, Gaspar C, Dion Y, Lespérance P, Tellier G, Richer F, Chouinard S, Rouleau GA (2009) Association of intronic variants of the BTBD9 gene with Tourette syndrome. Arch Neurol 66:1267-1272

33. Crane J, Fagerness J, Osiecki L, Gunnell B, Stewart SE, Pauls DL, Scharf JM (2011) Family-based genetic association study of DLGAP3 in Tourette Syndrome. Am J Med Genet B 156B:108-114 
34. Herzberg I, Valencia-Duarte AV, Kay VA, White DJ, Müller H, Rivas IC, Mesa SC, Cuartas M, García J, Bedoya G, Cornejo W, Ruiz-Linares A, Kremeyer B (2010) Association of DRD2 variants and Gilles de la Tourette syndrome in a family-based sample from a South American population isolate. Psychiatr Genet 20:179-183

35. Karagiannidis I, Dehning S, Sandor P, Tarnok Z, Rizzo R, Wolanczyk T, Madruga-Garrido M, Hebebrand J, Nöthen MM, Lehmkuhl G, Farkas L, Nagy P, Szymanska U, Anastasiou Z, Stathias V, Androutsos C, Tsironi V, Koumoula A, Barta C, Zill P, Mir P, Müller N, Barr C, Paschou P (2013) Support of the histaminergic hypothesis in Tourette Syndrome: association of the histamine decarboxylase gene in a large sample of families. J Med Genet 50:760-764

36. Dehning S, Müller N, Matz J, Bender A, Kerle I, Benninghoff J, Musil R, Spellmann I, Bondy B, Möller H-J, Riedel M, Zill P (2010) A genetic variant of HTR2C may play a role in the manifestation of Tourette syndrome. Psychiatr Genet 20:35-38

37. Yoon DY, Rippel CA, Kobets AJ, Morris CM, Lee JE, Williams PN, Bridges DD, Vandenbergh DJ, Shugart YY, Singer HS (2007) Dopaminergic polymorphisms in Tourette syndrome: association with the DAT gene (SLC6A3). Am J Med Genet B 144B:605-610

38. Miranda DM, Wigg K, Kabia EM, Feng Y, Sandor P, Barr CL (2009) Association of SLITRK1 to Gilles de la Tourette Syndrome. Am J Med Genet B 150B:483-486

39. Paschou P, Feng Y, Pakstis AJ, Speed WC, DeMille MM, Kidd JR, Jaghori B, Kurlan R, Pauls DL, Sandor P, Barr CL, Kidd KK (2004) Indications of linkage and association of Gilles de la Tourette syndrome in two independent family samples: $17 \mathrm{q} 25$ is a putative susceptibility region. Am J Hum Genet 75:545-560

40. Taylor S (2013) Molecular genetics of obsessive-compulsive disorder: a comprehensive meta-analysis of genetic association studies. Mol Psychiatry 18:799-805

41. Arking DE, Cutler DJ, Brune CW, Teslovich TM, West K, Ikeda M, Rea A, Guy M, Lin S Jr, Cook EH, Chakravarti A (2008) A common genetic variant in the neurexin superfamily member CNTNAP2 increases familial risk of autism. Am J Hum Genet 82:160-164

42. Zheng P, Li E, Wang J, Cui X, Wang L (2013) Involvement of tryptophan hydroxylase 2 gene polymorphisms in susceptibility to tic disorder in Chinese Han population. Behav Brain Funct 9:6

43. Farrell MS, Werge T, Sklar P, Owen MJ, Ophoff RA, O'Donovan MC, Corvin A, Cichon S, Sullivan PF (2015) Evaluating historical candidate genes for schizophrenia. Mol Psychiatry 20:555-562

44. Pauls DL (2008) The genetics of obsessive compulsive disorder: a review of the evidence. Am J Med Genet Part C 148:133-139

45. Taylor S (2016) Disorder-specific genetic factors in obsessivecompulsive disorder: a comprehensive meta-analysis. Am J Med Genet B 171B:325-332

46. Castellan Baldan L, Williams KA, Gallezot J-D, Pogorelov V, Rapanelli M, Crowley M, Anderson GM, Loring E, Gorczyca R, Billingslea E, Wasylink S, Panza KE, Ercan-Sencicek AG, Krusong K, Leventhal BL, Ohtsu H, Bloch MH, Hughes ZA, Krystal JH, Mayes L, de Araujo I, Ding Y-S, State MW, Pittenger C (2014) Histidine decarboxylase deficiency causes tourette syndrome: parallel findings in humans and mice. Neuron 81:77-90

47. Lei J, Deng X, Zhang J, Su L, Xu H, Liang H, Huang X, Song Z, Deng H (2012) Mutation screening of the HDC gene in Chinese Han patients with Tourette syndrome. Am J Med Genet B 159B:72-76

48. Dong H, Liu W, Liu M, Xu L, Li Q, Zhang R, Zhang X, Liu S (2016) Investigation of a possible role for the histidine decarboxylase gene in Tourette syndrome in the Chinese Han population: a family-based study. PLoS ONE 11:e0160265
49. Deng H, Le WD, Xie WJ, Jankovic J (2006) Examination of the SLITRK1 gene in Caucasian patients with Tourette syndrome. Acta Neurol Scand 114:400-402

50. Keen-Kim D, Mathews CA, Reus VI, Lowe TL, Herrera LD, Budman CL, Gross-Tsur V, Pulver AE, Bruun RD, Erenberg G, Naarden A, Sabatti C, Freimer NB (2006) Overrepresentation of rare variants in a specific ethnic group may confuse interpretation of association analyses. Hum Mol Genet 15:3324-3328

51. Chou IC, Wan L, Liu SC, Tsai CH, Tsai FJ (2007) Association of the Slit and Trk-like 1 gene in Taiwanese patients With Tourette syndrome. Pediatr Neurol 37:404-406

52. Scharf JM, Moorjani P, Fagerness J, Platko JV, Illmann C, Galloway B, Jenike E, Stewart SE, Pauls DL, The Tourette Syndrome Association International Consortium for Genetics (2008) Lack of association between SLITRK1 var321 and Tourette Syndrome in a large family-based sample. Neurology 70:1495-1496

53. Zimprich A, Hatala K, Riederer F, Stogmann E, Aschauer HN, Stamenkovic M (2008) Sequence analysis of the complete SLITRK1 gene in Austrian patients with Tourette's disorder. Psychiatr Genet 18:308-309

54. Abelson JF, Kwan KY, O'Roak BJ, Baek DY, Stillman AA, Morgan TM, Mathews CA, Pauls DL, Rasin M-R, Gunel M, Davis NR, Ercan-Sencicek AG, Guez DH, Spertus JA, Leckman JF, Dure LS, Kurlan R, Singer HS, Gilbert DL, Farhi A, Louvi A, Lifton RP, Sestan N, State MW (2005) Sequence variants in SLITRK1 are associated with Tourette's syndrome. Science 310:317-320

55. Karagiannidis I, Rizzo R, Tarnok Z, Wolanczyk T, Hebebrand J, Nöthen MM, Lehmkuhl G, Farkas L, Nagy P, Barta C, Szymanska U, Panteloglou G, Miranda DM, Feng Y, Sandor P, Barr C, Paschou P (2012) Replication of association between a SLITRK1 haplotype and Tourette Syndrome in a large sample of families. Mol Psychiatry 17:665-668

56. McGrath LM, Yu D, Marshall C, Davis LK, Thiruvahindrapuram B, Li B, Cappi C, Gerber G, Wolf A, Schroeder FA, Osiecki L, O'Dushlaine C, Kirby A, Illmann C, Haddad S, Gallagher P, Fagerness JA, Barr CL, Bellodi L, Benarroch F, Bienvenu OJ, Black DW, Bloch MH, Bruun RD, Budman CL, Camarena B, Cath DC, Cavallini MC, Chouinard S, Coric V, Cullen B, Delorme R, Denys D, Derks EM, Dion Y, Rosário MC, Eapen V, Evans P, Falkai P, Fernandez TV, Garrido H, Geller D, Grabe HJ, Grados MA, Greenberg BD, Gross-Tsur V, Grünblatt E, Heiman GA, Hemmings SMJ, Herrera LD, Hounie AG, Jankovic J, Kennedy JL, King RA, Kurlan R, Lanzagorta N, Leboyer M, Leckman JF, Lennertz L, Lochner C, Lowe TL, Lyon GJ, MacCiardi F, Maier W, McCracken JT, McMahon W, Murphy DL, Naarden AL, Neale BM, Nurmi E, Pakstis AJ, Pato MT, Pato CN, Piacentini J, Pittenger C, Pollak Y, Reus VI, Richter MA, Riddle M, Robertson MM, Rosenberg D, Rouleau GA, Ruhrmann S, Sampaio AS, Samuels J, Sandor P, Sheppard B, Singer HS, Smit JH, Stein DJ, Tischfield JA, Vallada H, Veenstra-Vanderweele J, Walitza S, Wang Y, Wendland JR, Shugart YY, Miguel EC, Nicolini H, Oostra BA, Moessner R, Wagner M, Ruiz-Linares A, Heutink P, Nestadt G, Freimer N, Petryshen T, Posthuma D, Jenike MA, Cox NJ, Hanna GL, Brentani H, Scherer SW, Arnold PD, Stewart SE, Mathews CA, Knowles JA, Cook EH, Pauls DL, Wang K, Scharf JM (2014) Copy number variation in obsessive-compulsive disorder and tourette syndrome: a cross-disorder study. J Am Acad Child Adolesc Psychiatry 53:910-919

57. Alexander J, Potamianou H, Xing J, Deng L, Karagiannidis I, Tsetsos F, Drineas P, Zsanett T, Rizzo R, Wolanczyk T, Farkas L, Nagy P, Szymanska U, Androutsos C, Tsironi V, Koumoula A, Barta C, Sandor P, Barr C, Tischfield J, Paschou P, Heiman G, Georgitsi M (2016) Targeted re-sequencing approach of candidate genes implicates rare potentially functional variants in Tourette Syndrome etiology. Front Neurosci 10:428 